\title{
The Isolation of Staphylococcus epidermidis Bacteria in White Snapper Salted Fish (Lates calcalifer) from Sibolga City, North Sumatera Province
}

\author{
${ }^{1}$ Rafika Lestari, ${ }^{2}$ Masda Admi, ${ }^{3}$ Rastina Rastina, ${ }^{2}$ Maryulia Dewi, ${ }^{3}$ Nurliana Nurliana, ${ }^{4}$ Abdul Harris, ${ }^{5}$ Ginta Riady \\ ${ }^{1}$ Veterinary Education Study Program Faculty of Medicine, Syiah Kuala University, Banda Aceh \\ ${ }^{2}$ Microbiology Laboratory of the Faculty of Veterinary Medicine, Syiah Kuala University, Banda Aceh \\ ${ }^{3}$ The Veterinary Public Health Laboratory, Faculty of Veterinary Medicine, Syiah Kuala University, Banda Aceh \\ ${ }^{4}$ Pharmacology Laboratory of the Faculty of Veterinary Medicine, Syiah Kuala University, Banda Aceh \\ ${ }^{5}$ Reproduction Laboratory of the Faculty of Veterinary Medicine Syiah Kuala University, Banda Aceh \\ Corresponding author: Rafika Lestari: rafikalestari04@gmail.com \\ Co-author: MA: admi.masda@gmail.com, RR: rastina.rzl@yahoo.co.id, MD: maryuliad@gmail.com,NN: \\ nurliana.nuna@unsyiah.ac.id, AH: harris.fkh@gmail.com, GR: ginta_riady@unsyiah.ac.id,
}

Submitted: $10 / 03 / 2020$ Revised: 29/03/2020 Accepted: 05/04/2020 Published online: 21/04/2020 doi: https://doi.org/10.35308/j-kesmas.v7i1.1918 How to cite this article: Lestari, R., Admi, M., Rastina, R., Dewi, M., Nurliana, N., Haris, A., \& Riady, G. (2020). The isolation of staphylococcus epidermidis bacteria in white snapper salted fish (lates calcalifer) of Sibolga City of North Sumatera Province. J-Kesmas: Jurnal Fakultas Kesehatan Masyarakat (The Indonesian Journal of Public Health. 7(1), 44-50.

\begin{abstract}
Salted fish is vulnerable to contamination by microbial. Staphylococcus epidermidis is one of the bacteria that can contaminate the salted fish. This research aims to isolate the Staphylococcus epidermidis bacteria contamination in salted white snapper fish sold in Sibolga City, North Sumatra Province. The sample used was white snapper salted fish, amounting to 10 samples from 10 traders. The isolation of Staphylococcus epidermidis was carried out using the Carter method. White snapper salted fish are mashed using a blender, then planted on Nutrient Broth (NB) as a bacterial growth media. Furthermore, identification of bacterial colonies grew using gram staining, Manitol Salt Agar (MSA) media, Blood Agar Plate (BAP) media, catalase test and confectionery media (Manitol and Glucose). The data obtained were analyzed descriptively. The results of this study suggest that Staphylococcus epidermidis contains bacterial contamination. Based on the data collected, it can be concluded that 7 out of 10 samples of white snapper salted fish sold in Sibolga City, North Sumatra Province, are contaminated with 70 percent Staphylococcus epidermidis bacteria.
\end{abstract}

Keywords: salted fish; Staphylococcus epidermidis; contamination

\section{Introduction}

Sibolga is one of the cities in the province of North Sumatra, recognized as the most abundant fish producing area in the world, where fisheries production in Sibolga has increased annually (Geffken et al., 2017). Sibolga is a town on the west coast of Sumatra with such great potential in the fisheries sector and it can also be said that the majority of the Sibolga communities' economy is driven by marine fishing (Sihite, 2013). Fish is a significant source of food for the body. Fish is also a food product that experiences decay and damage very quickly (Kamal et al., 2016). Traditionally, society often does the protection of fish by salting (Agustina et al. 2013). Fish preservation by salting is a way for fish not to decay quickly (Salosa, 2013). Salted fish products are also popular among the people, and salted fish is consumed in the community because it is easy to get, and also the price is relatively cheap so that people can enjoy it. Drying salted fish aims to increase the durability of the fish (Wardani \& Mulasari, 2016).

Viewed from the processing, salted fish is typically processed using traditional methods in Indonesia (Purnomo et al., 2017). The method of salted fish processing that is usually carried out by fishermen until now has not been hygienically carried out. It is very susceptible to the pollution that affects the shelf-life of fish when drying under direct sunlight (Marpaung, 2015). Viewed from the low level of fish freshness and unsafe food health and its processing techniques, the implementation of sanitation and hygiene in conventional fishery products processing technology is graded as poor 
(Akerina, 2018). The traditional way of preserving fish is aimed at reducing the amount of water content found in the fish's body, so this approach does not provide an opportunity for bacteria to multiply. In order to obtain preserves of high quality, good care during the preservation process is required, such as: maintaining the cleanliness of the tools and materials used, using fresh fish and using clean salt (Tuyu et al., 2014).

Most of the causes of infections caused by Staphylococcus epidermidis and Staphylococcus aureus have gained public attention because there has been a rise in infections caused by this type of bacteria worldwide in several years. Staphylococcus epidermidis is one of the bacteria that causes disease in humans, which is usually found in processed fishery products (Chessa et al., 2015). One of the signs of opportunistic pathogens caused by Staphylococcus epidermidis bacteria is the incidence of infection in humans who have weak immunity (Karimeila et al., 2018). Staphylococcus food poisoning is usually characterized by the sudden onset of symptoms including nausea, vomiting, cramps of the stomach and diarrhea (Asao et al., 2003). According to Faridz et al. (2007) things like this need to be considered mainly from the microbiological quality of food. The product is the number and type of microorganisms found in these foods. Contamination caused by Staphylococcus epidermidis bacteria in salted fish must be further tested in the Laboratory before consumption by the public. However, isolation of Staphylococcus epidermidis has never been done in white snapper salted fish in Sibolga City. Based on these problems researchers are interested in isolating Staphylococcus epidermidis bacteria in white snapper salted fish.

\section{Materials and Methods}

The study was conducted in November 2019 at the Microbiology Laboratory at the Faculty of Veterinary Medicine, Syiah Kuala University. Sample fish were collected from the salted fish market in Sibolga City, Province of North Sumatra. Ten samples of salted white snapper (Lates calcalifer) were used that was gathered from Sibolga City salt fish traders.
Taking into account the venue, the sampling method is completed. The location taken is a highway that often passes through vehicles such as motorcycles and cars, making it easy for customers to access. This study uses samples of white snapper salted fish (Lates calcalifer) for a total of 10 fish from each trader in the town of Sibolga. Every fish sample taken was put in one plastic box and another. The salted fish were then brought to the Faculty of Veterinary Medicine's Microbiology Laboratory at Syiah Kuala University.

\section{Research procedures}

The procedure of isolating Staphylococcus epidermidis was done by using Carter's method (1987). White snapper salted fish are mashed using a blender, then planted on the media Brut Nutrient (NB) as a medium for bacterial growth. Furthermore, identification of bacterial colonies that grew using gram staining, Manitol Salt Agar (MSA) media, Blood Agar Plate (BAP) media, catalase test and confectionery media (Manitol and Glucose).

\section{Bacteria isolation}

Fish samples were weighed as much as 2 grams, taken from 0.5 grams of the fish's head, 0.5 grams of the tail, 0.5 grams of the fish's right body, and 0.5 grams of the fish's left body. Besides, they were blended with a blender for 30 seconds until the texture of the fish meat is smooth, a sterile swab inserted into the blender. Next, enter the sterile swab into the media Nutrient Broth (NB). The tubes containing $10 \mathrm{ml}$ Nutrient Broth (NB) media were homogenized and incubated at $37 \mathrm{oC}$ for 24 hours, then the bacterial suspension was taken from the Nutrient Broth (NB) media, then scratched on Manitol Salt Agar (MSA) media. Bacteria that were inoculated into the Blood Agar Plate (BAP) were derived from Manitol Salt Agar (MSA) media with the T scratch technique and incubated at $370 \mathrm{C}$ for 24 hours. Staphylococcus epidermidis positive samples were planted on slanted Nutrient Agar (NA) media.

\section{Gram staining}

The process done in Gram staining is the disinfection of glass items with 70 percent alcohol. Physiological $\mathrm{NaCl}$ is dripped onto glass surfaces during disinfection. The ose loop is heated by 
including it on a methylated lamp. The bacterial colony is seized with ose on the Blood Agar Plate media, then positioned and homogenized on a glass object given physiological $\mathrm{NaCl}$ by forming a $1 \mathrm{~cm}$ diameter circle. Then the colony is left aerated to dry. The preparation is set by putting the glass item 2-5 times on the spirits lamp. The set preparations are then given 1-2 minutes of violet crystal dyeing.

Furthermore, the preparation is washed with running water. The preparations were then flooded with Lugol for 1 minute. After that, the preparation is washed with $96 \%$ alcohol for 5-10 seconds. Next, The preparations were saturated with safranin and left for 1 minute, then washed with running water and aerated. After drying, the preparations are dripped with emersion oil and microscopically examined at a magnification of 10 times.

\section{Catalase test}

Catalase testing was performed by taking separate bacterial colonies from the Manitol Salt Agar (MSA) and Blood Agar Plate (BAP) media, then exposing the bacterial colonies to glass objects, dropping $\mathrm{H}_{2} \mathrm{O}_{2} 3 \%$ in glass objects on bacterial colonies. The formation of air bubbles shows positive results which indicate the bacteria produce the enzyme catalase. If there are no visible air bubbles, the outcome is negative.

\section{Hemolysis test}

Test of hemolysis was carried out on medium Blood Agar Plate (BAP) with the aid of Ose, then inoculated on Blood-Agar Plate (BAP) mediums using the medium Manitol Salt Agar (MSA) and T streak technique.Media Blood Agar Plate (BAP) was incubated in an incubator for 24 hours at $37^{\circ} \mathrm{C}$.

\section{Sugar test (mannitol and glucose)}

A separate bacterial colony of the manitol is taken by sterile ose and inserted in a mannitolbearing testing tube by extracting sterile ose homogenously until the bacterial colony in the Ose became homogenous in the mannitol environment. It is taken into a separate bacterial colony by using sterile Ose. Next Bacteria Colony Incubate 24 hour mannitol at $37^{\circ} \mathrm{C}$. The same is correct for glucose.

\section{Data analysis}

The results of colony growth from the isolation of the Staphylococcus epidermidis bacteria were analyzed descriptively.

\section{Results}

Salted fish used in this analysis stood at ten samples from 10 traders around Sibolga Town. Table 1 shows the results of analyses of Staphylococcus epidermidis contamination in white snapper salted fish from 10 samples incubated at $37^{\circ} \mathrm{C}$ for 24 hours, can be seen in Table 1.

Data in the Table 1 consist of 10 salted fish samples obtained in Sibolga City showed a high prevalence rate of Staphylococcus epidermidis contamination rate which reached $70 \%$ where seven positive samples were contaminated with Staphylococcus epidermidis ie samples at traders 1, 2, $5,6,7,8$, and 10 while samples 3,4 , and 9 showed positive results that there were other bacterial contamination, besides Staphylococcus epidermidis other bacteria were also able to live on salted fish.

Tabel 1. Observation Result of Staphylococcus epidermidis contamination on the samples

\begin{tabular}{ccl}
\hline No & Sample & \multicolumn{1}{c}{ Bacteri } \\
\hline 1. & P 1 & Staphylococcus epidermidis \\
2. & P 2 & Staphylococcus epidermidis \\
3. & P 3 & non Staphylococcus epidermidis \\
4. & P 4 & non Staphylococcus epidermidis \\
5. & P 5 & Staphylococcus epidermidis \\
6. & P 6 & Staphylococcus epidermidis \\
7. & P 7 & Staphylococcus epidermidis \\
8. & P 8 & Staphylococcus epidermidis \\
9. & P 9 & non Staphylococcus epidermidis \\
10. & P 10 & Staphylococcus epidermidis \\
\hline
\end{tabular}




\section{Discussion}

The number of bacteria in fish is also highly influential on the freshness level. Damage to fish and processed goods such as salted food caused by spoilage bacteria has symptoms of damage such as a pungent smell, fly-infested, and unpleasant taste changes. The pungent odor is caused by the release of certain chemicals produced by spoilage bacteria such as $\mathrm{NH}_{3}$ and cadaverine. Stages of damage occur because the protein produces $\mathrm{NH}_{3}$ and $\mathrm{H}_{2} \mathrm{~S}$ with the help of peptides, free amino acids and vitamins, causing a specific odor discharge (Fifendy et al., 2017). Damage to processed fish products can be seen from the formation of brownish red or yellow spots on the surface of the fish's body and the presence of mucus (Marpaung, 2015). The bacteria that can survive in an atmosphere that has a high salt content are called halophilic bacteria, a group of bacteria that are included in halophilic bacteria (Fifendy et al., 2017).

Also, it can be considered both from the way of handling, sanitation, biological factors, environmental temperature, fish transportation equipment, and storage space can also affect the quality of salted fish produced (Riski et al., 2017). Based on observations made in the field, fish that are ready for sale are hanged at salted fish traders for $>12$ hours. Moreover, the location of the salted fish sales location is right on the side of the road, so that bacterial contamination can occur through the air that is around the merchant's place. The level of bacterial contamination illustrates how the condition of sanitation because the purpose of sanitation is to prevent the entry of contaminants into food and processing equipment used in food processing, and prevent recontamination (Susianawati, 2007), so that prevention of contamination can be done if sanitation from individuals can be improved.

Prevention of Staphylococcus epidermidis bacterial contamination can be done by paying more attention to the processing methods of processed salted fish products that are good starting from the process of selecting fresh fish, selecting clean salt, and weeding, cleaning and drying the fish done by paying attention to its cleanliness. Storage that is cool, dry, and has proper air ventilation is a desirable condition for storing salted fish products. Of course, salted fish when marketed must use a closed package to reduce the danger of contamination and pay attention to the level of maturity of the fish when cooking. In the process of salted fish, processing starts from weeding, washing, salting and drying stages. Where in the salting stage, it can be noted from the amount or content of salt used, the length of the salting period, as well as the drying time, are factors that can affect the final results of salted fish to be produced can be seen from the drying process. The selection of salt used as one of the preservation stages is also a determinant of the success of the processed fish salted result, which is salt with a level of smoothness, purity and right salt concentration and seen from the fish material used wherein getting good quality is determined by the freshness of the fish, the content and thickness of the fish (Marpaung, 2015).

Preserving fish by combining the stages of salting and drying can provide a double benefit where salted fish products will be more durable because the purpose of the fish salting and drying stages is to reduce the level of water contained in the body of the fish. The close relationship between low water content and the durability of processed fish products will result in better durability of processed fish products. This is because, in the occurrence of enzymatic and chemical processes as well as the growth of bacteria, a certain amount of water is needed. Decreased water content in the material will inhibit the growth of spoilage bacteria.

Based on the results of bacterial isolation on the media of Manitol Salt Agar (MSA) which was planted at $37^{\circ} \mathrm{Cfor} 24$ hours, it was marked by a change in the color of the media from red to beige and visible convex-shaped colonies with flat edges. Jamaluddin et al. (2016) which states to be able to distinguish between Staphylococcus epidermidis and Staphylococcus aureus, can use the media of Manitol Salt Agar (MSA). Where the S. aureus bacteria can ferment Manitol so that it can change the Manitol Salt Agar (MSA) medium from red to golden yellow while the Staphylococcus epidermidis cannot ferment Manitol, shown in Figure 1. 


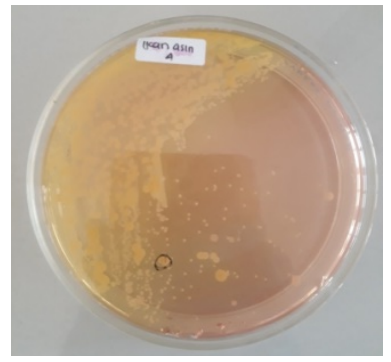

Figure 1. Stapyhlococcus epidermidis colony from Trader 1 sample on Manitol Salt Agar (MSA) media.

Staphylococcus sp. Bacteria are facultative anaerobic bacteria and do not form spores. Growth temperature ranges from $6.5^{\circ} \mathrm{C}-40^{\circ} \mathrm{C}$ with optimal growth occurring at $37^{\circ} \mathrm{C}$. This bacterium can grow in the range of $\mathrm{pH}$ values 4.2 - 9.3. Staphylococcus $s p$ is a pathogenic bacterium that has the ability to produce enterotoxins which can be a disease caused by consuming contaminated food (Pailu and Budiarso, 2017). Enterotoxins are enzymes that can survive in hot conditions and are resistant in an alkaline atmosphere in the intestine which can cause food poisoning (Rahayu et al., 2014). Prevention of bacterial contamination of Staphylococcus sp can be done by observing the storage temperature of fish and when the fish is cooked until cooked, usually poisoning when consuming food can occur because the food is not stored at high enough temperatures $\left(\geq 60^{\circ} \mathrm{C}\right.$ ) or cold enough $\left(\leq 7.2^{\circ} \mathrm{C}\right.$ ) (Hayu, 2018).

Salted fish sold in Sibolga City should be paid more attention both in terms of the place of sale and during processing so that contamination can be reduced. Bacterial growth on Manitol Salt Agar (MSA) media which was then identified by Gram staining. From the gram staining results obtained, bacterial colonies look purple, which states the bacteria are gram-positive. Gram-positive bacteria have a thicker peptidoglycan wall compared to gramnegative bacteria so that at the time of staining, grampositive bacteria can bind to a violet crystal dye. Gram staining results observed under a microscope show the form of bacteria microscopically is a way to see the characteristics of a round bacterium. In this research, it was found that the bacteria were round, which meant that they belonged to the cocci group (Safrida et al., 2012) as shown in Figure 2.

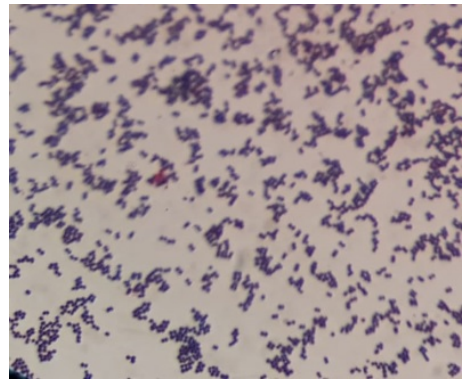

Figure 2. The results of Gram Staphylococcus epidermidis staining

Salted fish samples that have been able to grow on the media of Manitol Salt Agar (MSA) are then further identified by the catalase test, then to see the ability of bacteria in blood hemolysis is done by using the media Blood Agar Plate (BAP) followed by planting on a sugar medium (Mannitol and Glucose). Based on the results of the examination on the catalase test, hemolysis test and sugar test there are seven samples of traders showing positive results of the Staphylococcus epidermidis bacteria, that is, traders samples $1,2,5,6,7,8$, and 10. The positive catalase test results in the presence of air bubbles. The result of the hemolysis test is the formation of the $\gamma$ - hemolysin zone and the sugar test shows negative mannitol and positive glucose.

\section{Conclusion}

Tests from 10 salted fish traders in Sibolga City showed that 7 out of 10 salted fish samples tested 70 percent contaminated with Staphylococcus epidermidis bacteria in white snapper (Lates calcalifer).

\section{Acknowledgement}

Thank you, from the authors to the Dean of the Faculty of Veterinary Medicine at Syiah Kuala University.

\section{Author Contribution and Competing Interest}

Rafika Lestari and MD carried out the research. DD and RR conceptualized this research. $\mathrm{NN}, \mathrm{AH}$, and GR revised the manuscript. All authors read and approved the final manuscript. There was no competing interest related to the conduct of this study. 


\section{Publisher's Note}

J-Kesmas: Jurnal Fakultas Kesehatan Masyarakat (Indonesia Journal of Public Health) remains neutral with regard to jurisdictional claims in published institutional affiliation.

\section{References}

Agustina, D., Yulvizar, C., \& Nursanty, R. (2013) Isolation and characterization of bacteria in mackerel Salted fish. Bio Spesies, 6(1):15-19.

Akerina, F.O. (2018) Microbial contamination of smoked tuna in several traditional tobelo markets, North Halmahera, Indonesia. J. Aquaculture, Coastal and Small Islands, 2(1):17-21.

Asao, T., Kumeda, Y., Kawai, T., Shibata, T., Oda, H., Haruki, K., Nakazawa, H., \& Kozaki, S. (2003) An extensive of Staphylococcal food poisoning due to low-fat milk in japan: estimation of enterotoxin $a$ in the incriminated milk and powered skim milk. Epidemol Infect. 130: 33-40.

Carter, G.R. (1987) Essentials of veterinary bakteriologi and micology. $3^{\text {rd }}$ ed. Lea and Febriger. Philadelphia.

Chessa, D., Ganau, G., \& Mazzarello, V. (2015) An overview of Staphylococcus epidermidis and Staphylococcus aureus with a focus on developing countries. $J$. Infection in Developing Countries, 9(6): 547-550.

Faridz, R., Hafiluddin, \& Anshari, M. (2007) Analysis of the number of bacteria and the presence of Escherichia coli in anchovy processing at PT. Manage marine units in the Sumenep unit. EMBRYO, 4(2): 94-106.

Fifendy, M., Rattriana, F., \& Irdawati (2017) Isolation and identification of halophilic gutters (Chorinrmus sp) from Aia Bangih Pasaman Barat, J. BioScience. 1(2): 21-28.

Geffken, R., Hendrik., \& Zulkarnain. (2017). Analysis of salted fish processing business in Pondok Batu Village, Sarudik District, Sibolga City, North Sumatra Province. JOM, 4(1): $1-9$.

Hayu, R.E. (2018) Staphylococcus Sp. bacterial contamination in extraordinary events of food poisoning in Sawangan Hamlet, Magelang
Regency, Central Java, Indonesia. Journal of Public Health Sciences, 7(2):22-32.

Jamaluddin, Suryanto, D., \& Lesmana, I. (2016) Types of gram-positive bacterial pathogenic potential in milkfish (Chanos chanos) in the pond of Tanjung Rejo Paluh Putri Percut Sei Tuan village. J. Aquacoastmarine, 4(4): 2-10.

Kamal, S., Nurliana., Jamin, F., Sulasmi., Hamny., \& Fakhrurrazi. (2016) Total psychotropic bacteria of tilapia (Oreochromis niloticus) given an increase in temperature at the time of maintenance. Veterinarian Medical $J$. 10(1) : $37-40$

Karimella, E.J., Ijong, F.G., Palawe, J.F.P., dan Mandeno, J.A. (2018) Isolation and identification of Staphylococcus epidermidis bacteria in pinekuhe smoked fish, $J$. Fisheries and Marine Technol. 9(1) :35-42.

Kateete, D.P., Kimani, C.N., Katabazi, F.A., Okeng, A., Okee, M.S., Nanteza, A., Joloba, M.L., and Najjuka, F.C. (2010) Identification of Staphylococcus aureus: Dnase and manitol salt agar improve the efficiency of the tube coagulase test. Annals of Clinical Microbiol. Antimicrob., 9(23): 1-7.

Marpaung, R. (2015) Microbiological studies on dried salted fish products marketed in traditional markets and supermarkets in an effort to improve food safety in Jambi City. Batanghari University Jambi Scientific J, 15(3): 145-151.

Mulyono, M. (2011) White Snapper Cultivation (Lates calcalifer bloch). Center for Maritime and Fisheries Counseling Development Agency for Maritime and Fisheries Human Resources, Ministry of Maritime Affairs and Fisheries.

Pailu, P.T., dan Budiarso, T.Y. (2017) Isolation and identification of Staphylococcus sp in powdered infant milk. AIP Conference Proceedings, 1844-1908.

Purnomo, I.M.H., Lestari, S.D. dan Baehaki, A. (2017) Analysis of the content of formaldehyde, pesticides, and mushrooms in several types of salted fish. J. Fisheries Product Technol. 6(1): 47-55.

Puspita, E.R., Yanuartono, Hartati, S., Rahardjo, S., Nururrozi, A., dan Indarjulianto, S. (2018) 
Isolation and identification of Staphylococcus epidermidis in cow's milk PFH patients with subclinical mastitis in Wukirsari, Cangkringan, Sleman DIY. J. Anim. Husbandry, 28(2): 121-128.

Rahayu, N.P.N., Kawuri, R. Dan Suriani, N.L. (2014). Staphylococcus aureus civilization test on traditional sausages (sequence) circulating in the traditional market of Denpasar, Bali. J. Symbiosis, 2(1): 147-157.

Rahmani, Yunianta, \& Martati, E. (2007) Effect of wet salting method on the characteristics of cork (Ophiocephalus striatus) salted fish products. J. Agric. Technol., 8(8): 142-152.

Riski, K., Fakhrurrazi., \& Abrar, M. (2017). Isolation of Staphylococcus aureus bacteria in salted gutters (Scomberoides commersoniaus) in Leupung District, Aceh Besar Regency. Vet. Student Scientific J. 1(3): 366-374.

Safrida, Y.D., Yulvizar, C., \& Devira, C.N. (2012). Isolation and characterization of potentially probiotic bacteria in mackerel (Rastrelliger sp). Depik J., 1(3): 200-203.

Sakti, H., Lestari, S., \& Supriadi, A. (2016) Changes in the quality of cork fish (Channa striata) smoke during storage. J. Fisheries Product Technol., 5(1): 11-18.
Salosa, Y.Y. (2013) Test the levels of formaldehyde, salt content and total mackerel salted fish bacteria from the Regency of Papua Province. Depik J., 2(1): 10-15.

Sihite, H.H. (2013) Study of the utilization of fish waste from fish auction sites (TPI) and Nauli Sibolga traditional markets into fish flour as raw material for animal feed. J. Unimal Chemical Technol. 2(2): 43-54.

Sukmawati., \& Hardianti, F. (2018) Analysis of microbial total plate count (TPC) in snapper salted fish in Sorong City, West Papua. $J$. Biodjati, 3(1): 72-78.

Susianawati, R., Sya'rani, L., \& Agustini, T.W. (2007) Study of GMP and SSOP application on dried salted fish products in an effort to improve food safety in Kendal Regency. Sea Sand J., 2(2): 40-53.

Tuyu, A., Onibala, H., \& Makapedua, D.M. (2014) The old study of salted fish (Selaroides sp) drying was related to water content and organoleptic value. J. Fisheries Product Technol. Media, 2(2): 20-26.

Wardani, R.I. \& Mulasari, A. (2016) Identification of formaldehyde in salted fish sold in the coastal area of Turtle Bay in Cilacap Regency. J. Pub. Health, 10(1): 43-48. 